\title{
Morphological variations and sexual dimorphism in Chelonoidis carbonaria (Spix, 1824) and Chelonoidis denticulata (Linnaeus, 1766) (Testudinidae)
}

\author{
Barros, MS. ${ }^{\text {a }}$, Resende, $L C .^{\text {b }}$ Silva, $A G^{\text {c }}{ }^{\mathrm{c}}$ and Ferreira Junior, $P D .^{\mathrm{c} *}$ \\ aUniversidade Federal de Viçosa - UFV, Av. PH Rolf's, s/n, sala 111, Centro, CEP 36571-000, Viçosa, MG, Brazil \\ ${ }^{b}$ Departamento de Zoologia, Instituto de Ciências Biológicas, Universidade Federal de Minas Gerais - UFMG, \\ Av. Antonio Carlos, 6627, Pampulha, CEP 31270-910, Belo Horizonte, MG, Brazil \\ 'Universidade Vila Velha - UVV, Rua Comissário José Dantas de Melo, 21, Boa Vista, \\ CEP 29102-770, Vila Velha, ES, Brazil \\ *e-mail: pdfj@hotmail.com
}

Received October 28, 2010 - Accepted January 4, 2011 - Distributed February 29, 2012

(With 1 figure)

\begin{abstract}
Chelonoidis Dcarbonaria and C. denticulata are two tortoises which are widely distributed Brazil. Although they occur sympatrically in different areas, $C$. carbonaria prefers open areas, while $C$. denticulata chooses forest areas. Significant morphological variations can be observed in these species due to the fact that they occupy a vast and environmentally diverse area. Data on shell shape of captive individuals reveal important differences between the two species, mainly in the plastron scutes, carapace width, and head length. Variation in shape is greater in C. carbonaria than in C. denticulata, which may be associated to a more elaborate and complex mating ritual. The shell shape in $C$. denticulata is more elongated than in $C$. carbonaria due to ecological habits. These aspects lead to a greater restriction in shape, limiting variation and dimorphism. In C. carbonaria, the shell opening is larger than in $C$. denticulata, which affords greater variation in shape. A more elongated shell facilitates movements of $C$. denticulata in densely forested areas. Yet, this characteristic reduces shell opening, lessening the possibilities of variation in form.
\end{abstract}

Keywords: tortoise, carapace, plastron, shape.

\section{Variações morfológicas e dimorfismo sexual em Chelonoidis carbonaria (Spix, 1824) e Chelonoidis denticulata (Linnaeus, 1766) (Testudinidae)}

\begin{abstract}
Resumo
Chelonoidis carbonaria e $C$. denticulata são duas espécies de jabutis com ampla distribuição no território brasileiro. Apesar de ocorrerem em simpatria em muitos locais, $C$. carbonaria apresenta predileção por áreas mais abertas e C. denticulata, por áreas de florestas mais densas. Por ocuparem extensa área com grandes variações ambientais, essas espécies apresentam grande variação nas características morfológicas. Dados da forma do casco de indivíduos cativos indicam importantes diferenças entre as espécies, principalmente nos escudos do plastrão, na largura da carapaça e no comprimento cefálico. Chelonoidis carbonaria apresenta maior variação da forma que $C$. denticulata, o que pode ser relacionado a um ritual de acasalamento mais elaborado e complexo. Chelonoidis denticulata possui corpo mais alongado que $C$. carbonaria, o que é atribuído aos seus hábitos; esse aspecto leva a uma maior restrição da forma, minimizando as possibilidades de variação do seu dimorfismo. A abertura no casco de C. carbonaria é maior que em C. denticulata, o que possibilita maior variação na forma. Um casco mais alongado facilita o deslocamento de $C$. denticulata em áreas de floresta densa, mas reduz a abertura desse casco, diminuindo as possibilidades de variação da forma.
\end{abstract}

Palavras-chave: jabuti, carapaça, plastrão, forma. 


\section{Introduction}

The red-footed tortoise Chelonoidis carbonaria, locally known in Brazil as "jabutipiranga", and the yellow-footed tortoise Chelonoidis denticulata, called "jabutitinga", are two tortoises which are widely distributed in Brazil. Together with $C$. chilensis (Gray, 1870) and C. nigra (Quoy and Gaimard, 1824) (recorded only in the Galapagos Islands), C. carbonaria and $C$. denticulata are representatives of the order Testudines in South America. Chelonoidis carbonaria and $C$. denticulata are very similar in morphological, behavioral and reproductive traits (Farias et al., 2007). These species are considered mid-sized, with a mean straight carapace length in $C$. carbonaria rarely exceeding $50 \mathrm{~cm}$ (Pritchard and Trebbau, 1984), and individuals with carapaces varying between 30 and $40 \mathrm{~cm}$ in length are more commonly observed (Jerozolimski, 2005). Chelonoidis denticulata occurs preferably in humid tropical forests, while $C$. carbonaria prefers clearing and dry areas typical of savanna and caatinga. However, the two species are commonly observed to occur in sympatry, mainly in transition areas between humid forests and the cerrado (Farias et al., 2007; Moskovits, 1998; Pritchard and Trebbau, 1984; Moreira, 1989; Jerozolimski, 2005; Vinke et al., 2008).

Hagan (1989) pointed out the main characteristics whereby the two species can be distinguished: inguinal scute form, the relationship between the femoral and humeral suture size, i.e. if the gular scute overlaps or does not reach the carapace, and the growth form of the carapace and prefrontal scales. A distinctive trait commonly used to differentiate the species is the head and limb color, although this characteristic may lead to erroneous interpretations due to the wide variation in color patterns. Mistakes in classifications that mainly use the color are frequent and go back to the first texts about the species (Vanzolini, 1999). A review of the identification characteristics and of scute patterns in C. carbonaria and C. denticulata is given in Jerozolimski (2005) and Vinke et al. (2008).

To occupy a broad area with great environmental variations, the species present a great variation in morphological characteristics (Pritchard and Trebbau, 1984). According to Guix et al. (2001), apparently the variation in the scutelation pattern can be caused due to environmental changes. Breeding in captivity can lead C. carbonaria to the development of morphological, behavioral, and reproductive abnormalities when hatchlings originating from a region grow in other areas, environmentally diverse from the one where they were born, and it leads to the masculinization of females (Guix et al. 2001).

When natural selection (manifested as the search for shelter, food or protection against predators) does not restrict bodies to a more uniform design, sexual selection (characters associated to mating) and selection for fecundity (observed as larger bodies) play a more prominent role causing more significant dimorphism (Bonnet et al., 2001). Species of one same taxon exposed to different kinds of environmental pressure can develop variation in sexual size dimorphism (Willemsen and Hailey, 2003; Lovich et al., 2010).

A considerable morphological variation in the turtle population is commonly observed, although the quantification of this variation and the establishment of the evolutive processes that have shaped it are a very difficult task due to the complex interactions between the phenotype, locomotor development, and behavior (Delmas et al., 2007). These morphological variations may be caused by selection pressure or by ecological habits, such as predation. Additionally, the availability of food resources and even reproductive behaviors also seem to influence morphology (Morafka, 1982; Germano, 1993; Willemsen and Hailey, 2003). In this scenario, biometric analysis is important as it may provide information on the degree of divergence between species and populations (Leary et al., 2003; Fernández and Rivera, 2003; Lindeman, 2003; Boone and Holt, 2001).

This study analyses the morphological variations in the shell of $C$. carbonaria and $C$. denticulata in an effort to establish the relationship between morphological differences and sexual dimorphism and to the species' reproductive behavior.

\section{Material and Methods}

We analysed 154 adult tortoises: 132 C. carbonaria $(80$ males and 52 females) and 22 C. denticulata (11 males and 11 females). Individuals came from the USIPA/CEBUS Zoo in Ipatinga, Minas Gerais, Brazil. It was not possible to determine the origin of the tortoises because they had been donated to the zoo. In general, hatchlings are captured in the far northern and northeastern areas of Brazil and sold as pets on Brazilian roads. Their final destinations are usually urban centers in the south and southeast of Brazil. Adult tortoises are less appealing to the general population and, when young tortoises grow up, they end up being donated to zoos, taken to environmental authorities, or simply released into woods (Souza et al., 2007).

We determined the sex of individuals based on plastron hollow, anal scute gap, tail shape and reproductive behavior (copula and nest digging) (Pritchard and Trebbau, 1984). Only sexually mature individuals were used. Only adult C. denticulata larger than $290 \mathrm{~mm}$ in carapace length (CL) and C. carbonaria larger than $190 \mathrm{~mm}$ in CL were included. In order to minimize the effects associated with sexual dimorphism, males and females were analyzed separately. We measured the weight of each individual (W), as well as another 20 morphological traits in a straight-line using calipers $( \pm 1 \mathrm{~mm})$ : plastron length $(\mathrm{PL})$; carapace length (CL); curved carapace length (CCL); carapace width at the junction of the $5^{\text {th }}$ and $6^{\text {th }}$ marginal scutes (CW5-6); carapace width at the junction of the $7^{\text {th }}$ and $8^{\text {th }}$ marginal scutes (CW7-8); shell height at the junction of the $2^{\text {nd }}$ and $3^{\text {rd }}$ marginal scutes ( $\left.\mathrm{SH} 2-3\right)$; shell height at the junction of the $3^{\text {rd }}$ and $4^{\text {th }}$ marginal scutes (SH3-4); shell height at the junction of the $6^{\text {th }}$ and $7^{\text {th }}$ marginal scutes (SH6-7); shell height at the junction of the $8^{\text {th }}$ and $9^{\text {th }}$ marginal scutes 
(SH8-9); distance between auxiliary and inguinal scute (AX-IN); humeral scute width (HSW); width of suture between pectoral scute and abdominal scute (PS-AS); width of suture between abdominal scute and femoral scute (AS-FS); bridge width (bridge); anal scute length (ASL); anal scute width (ASW); humeral median suture length (HMSL); femoral median suture length (FMSL); inguinal scute width (ISW); head width (HW); and head width (HL). In total, 21 parameters were assessed.

\subsection{Statistical analysis}

The differences in sexual dimorphism in each species were analyzed using ANCOVA, with the straight carapace length as a covariable in order to rule out the effect of size on form (Bonnet et al., 2001; Willemsen and Hailey, 2003). The morphometric parameters measured were logtransformed for normalization, which was observed using the $\mathrm{K}^{2}$ test, considering kurtosis and symmetry of the dataset as normality indicators (Zar, 2009). The discriminant analysis was carried out using the 21 morphometric parameters listed above. The analysis adopted the saturated model with the 21 parameters, which were progressively excluded when not offering a significant contribution to explain the total variation contained in the morphometric matrix.

The consistency of parameters between sexes in the two species was observed using Wilks lambda. The capacity to explain the variation in the dataset was expressed by the characteristic values in the standardized matrix. Individuals were classified into the groups, so as to estimate the discriminant function and insert each individual into the group whose centroid was the closest to the value observed.

The success rate of the discriminant function was estimated using the $\chi^{2}$ test and Mahalanobis' generalized distance. The 5\% significance level to test the discriminant function was established based on Wilks lambda, LawleyHotelling trace, and the Pillai's test. The discriminant analysis and the respective diagnosis were performed using the Systat 11.0 software for Windows.

\section{Results}

The discriminant function for the differentiation of individuals in terms of sex and species was estimated using 13 of the 21 parameters (Table 1) in a model that afforded high significance (Wilks lambda $=0.068$; $\mathrm{df}=13$; $\mathrm{F}=15,000 ; \mathrm{df}=39 ; p>0.01)$.

The groups formed by the estimated canonical variables were consistent and ranked together the individuals with a global correct classification score of $91 \%$. The worst classification score was observed for $C$. denticulata females $(75 \%)$, which have a smaller number of components (Table 2). The Jackknife cross validation was able to correctly classify $86 \%$ of individuals into the respective groups. The lowest correct classification percentages were 67 and $73 \%$ for groups of $C$. denticulata males and females, respectively, and the two less numerous groups, with a global correct classification of $86 \%$ (Table 3 ).

The eigenvalues of canonical variables were highly significant in the test conducted in the matrix trace, revealing the consistency of the classification capacity based on the calculated discriminant function (Pillai's test $=1.60$, $\mathrm{F}=11.86, \mathrm{df}=39, p>0.01$; Lawley-Hotelling trace $=5.34$, $\mathrm{F}=18.02, \mathrm{df}=39, p>0.01)$. The PC1 and PC2 accumulated $95.5 \%$ of the total dispersion contained in the original data matrix. The lowest correlation coefficient between the data observed and the two canonical axes calculated was 0.80 , however other proof of the robustness of the discriminant analysis was conducted.

The first axis (PC1), in the dispersion diagram generated by the canonical analysis, is associated to species, while the second axis (PC2) represents sex (Figure 1). The most important variables in species differentiation were related

Table 1. Coefficients associated to the morphometric variables used to estimate the canonical discriminant function, considering sex and species as descriptors in Chelonoidis carbonaria and C. denticulata.

\begin{tabular}{lrrr}
\hline \multicolumn{1}{c}{ Variable } & PC1 & PC2 & PC3 \\
\hline Constant & 6.105 & -5.511 & 0.600 \\
CCL (curved carapace length) & 14.001 & 1.330 & 30.013 \\
SH2-3 (shell height at the junction of $2^{\text {nd }}$ and (rd $^{\text {rd }}$ marginal scutes) & -11.562 & 0.273 & -1.218 \\
CW5-6 (carapace width at the junction of $5^{\text {th }}$ and 6 ${ }^{\text {th }}$ marginal scutes) & 10.549 & 16.499 & -5.232 \\
CW7-8 (carapace width at the junction of $7^{\text {th }}$ and $8^{\text {th }}$ marginal scutes) & 13.376 & -0.185 & -25.343 \\
PL (plastron length) & -10.668 & 2.690 & 13.711 \\
PS-AS (width in suture between pectoral scute and abdominal scute) & -11.896 & -18.907 & -0.549 \\
LCPAN (anal scute length) & 0.027 & -4.353 & -1.616 \\
AX-IN (distance between auxiliary and inguinal scute) & -10.188 & 20.245 & -6.103 \\
HW (head width) & 6.514 & -4.194 & -10.242 \\
HL (head width) & -0.718 & -11.497 & -7.225 \\
HSW (humeral scute width) & -14.894 & -1.542 & 1.699 \\
FMSL (femoral median suture length) & 5.768 & -7.680 & 3.299 \\
ISW (inguinal scute width) & 3.733 & 3.997 & -1.745 \\
\hline
\end{tabular}


Table 2. Classification matrix of the cases observed in the groups formed according to the discriminant function estimated in Chelonoidis carbonaria and C. denticulata.

\begin{tabular}{lccccc}
\hline $\begin{array}{c}\text { Group } \\
\text { estimated }\end{array}$ & $\begin{array}{c}\text { C. carbonaria } \\
\text { (female) }\end{array}$ & $\begin{array}{c}\text { C. carbonaria } \\
\text { (male) }\end{array}$ & $\begin{array}{c}\text { C. denticulata } \\
\text { (female) }\end{array}$ & $\begin{array}{c}\text { C. denticulata } \\
\text { (female) }\end{array}$ & $\begin{array}{c}\text { \% Correct } \\
\text { estimates }\end{array}$ \\
\hline C. carbonaria (female) & 45 & 2 & 0 & 1 & 94 \\
C. carbonaria $($ male) & 7 & 71 & 0 & 0 & 91 \\
C. denticulata $($ female) & 0 & 0 & 10 & 1 & 91 \\
C. denticulata (female) & 1 & 0 & 2 & 9 & 75 \\
\hline Total & 53 & 73 & 12 & 11 & 91 \\
\hline
\end{tabular}

Table 3. Classification matrix constructed by cross-validation of observed cases using the Jackknife method in groups defined according to the estimated discriminant function in Chelonoidis carbonaria and C. denticulata.

\begin{tabular}{lccccc}
\hline $\begin{array}{c}\text { Estimated } \\
\text { group }\end{array}$ & $\begin{array}{c}\text { C. carbonaria } \\
\text { (female) }\end{array}$ & $\begin{array}{c}\text { C. carbonaria } \\
\text { (male) }\end{array}$ & $\begin{array}{c}\text { C. denticulata } \\
\text { (female) }\end{array}$ & $\begin{array}{c}\text { C. denticulata } \\
\text { (female) }\end{array}$ & $\begin{array}{c}\text { \% Correct } \\
\text { estimates }\end{array}$ \\
\hline C. carbonaria (female) & 41 & 5 & 0 & 2 & 85 \\
C. carbonaria $($ male) & 7 & 71 & 0 & 0 & 91 \\
C. denticulata $($ female) & 0 & 0 & 8 & 3 & 73 \\
C. denticulata (female) & 1 & 1 & 2 & 8 & 67 \\
\hline Total & 49 & 77 & 10 & 13 & 86 \\
\hline
\end{tabular}

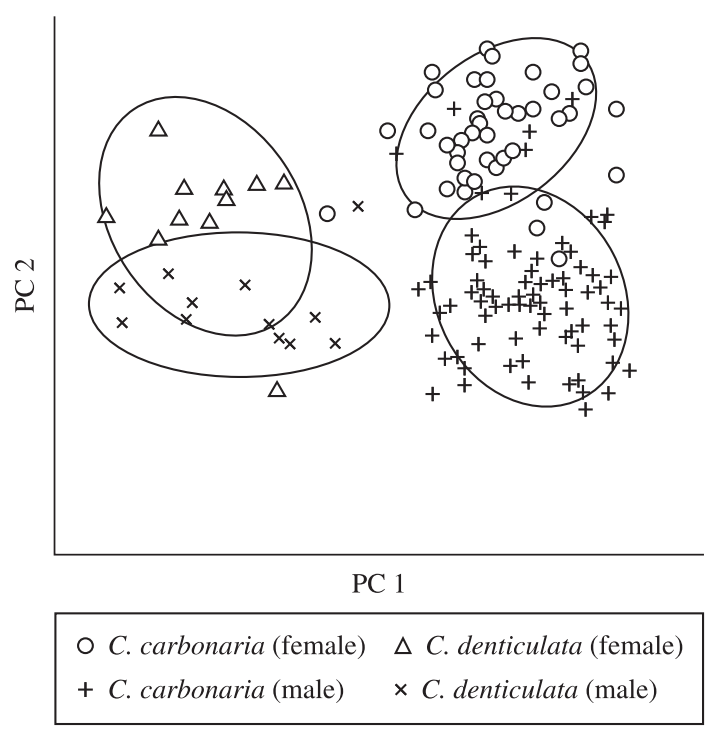

Figure 1. Dispersion diagram of the discriminant analysis conducted for the morphometric variables in females (o) and males $(+)$ of $C$. carbonaria, and of females $(\Delta)$ and males (x) of $C$. denticulata.

to the dimensions of the plastron scute (HSW, PS-AS, AX-IN and PL), the curved carapace length (CCL) and carapace constriction (CW7-8, CW5-6). AX-IN is larger in C. denticulata, which favors a more rigid structure and has greater protection as the increase in AX-IN is associated to increased bridge width, narrowing the opening available for limb movement and exposure. Chelonoidis denticulata presented a greater gular scute, which decreases the pectoral scute compared to $C$. carbonaria.

In C. denticulata, PS-AS is larger than in C. carbonaria, although CW7-8 and CW5-6 are smaller in C. denticulata. These two measurements were made in the central section of the carapace and plastron and point to a constriction in that region. Nevertheless, this constriction is bigger in the carapace of $C$. carbonaria than in the plastron of C. denticulata. CCL is larger in C. carbonaria, which is due to the greater dome-like character or to the roundness in this species. Shell height (SH2-3) is larger in C. denticulata, which has a less rounded shape and a larger frontal angle. This characteristic may also be advantageous to males during fights as it makes it more difficult for the contender to stretch the head and shell.

As to the variables related to sex (PC2), the highest values were observed for AX-IN, PS-AS, CW5-6, and HL. The greater AX-IN in females affords more protection, in spite of the lower mobility caused by the lesser room available for limb movements. Females also presented a larger CW5-6, which may be associated to a larger body and to increased egg production. In turn, males presented larger PS-AS, which is related to plastron concavity and reflects an adaptation trait in copulating and mounting on females. Males also showed larger HL, which may be related to the fighting behavior.

No sex dimorphism was observed concerning size in the individuals assessed. The carapace length (CL) and weight did not vary in the males of the two species (Table 4). The measurements of anal scutes (ASL and ASW) were also significantly different in males as compared to females, in both species. The differences in scute size are greater in C. carbonaria than in C. denticulata (Table 5). In 
C. carbonaria, these measurements presented the greatest differences after the correction considering carapace length (ANCOVA). In C. carbonaria females, ASL was $32.1 \%$ smaller than in males. In males, these differences facilitate tail movement, due to the larger space available, while in females it affords greater protection.

When the morphometric measurements obtained in the present study are compared to those previously reported for $C$. denticulata and $C$. carbonaria native of the State of Pará, Brazil, sexual dimorphism was observed to run along the same direction in both datasets (Jerozolimski, 2005). In both species, CL, CCL, CW7-8 PS-AS and AS-FS in males were larger than in females, while the contrary was observed for CW5-6 and SH6-7. The only discrepancy

Table 4. Diagnosic parameters for the canonical variables estimates using the discriminant function calculated for identification of sex and species in Chelonoidis carbonaria and $C$. denticulata.

\begin{tabular}{lccc}
\hline \multicolumn{1}{c}{ Diagnosis parameters } & PC1 & PC2 & PC3 \\
\hline Characteristic value & 3.36 & 1.74 & 0.24 \\
Canonical correlations & 0.88 & 0.80 & 0.44 \\
\% Accumulated of total dispersion & 63.0 & 95.5 & 100.0 \\
\hline
\end{tabular}

observed concerned the PL of $C$. denticulata females, which were reported to be $0.84 \%$ larger than males in the previous study, while in the present investigation females were observed to be $5.4 \%$ smaller than males.

\section{Discussion}

The main differences in the shell shape between C. carbonaria and $C$. denticulata lie in the plastron. The humeral scute width (HSW) is a criterion to distinguish these two species, especially when measured along with PS-AS, AX-IN, and PL. The combined utilization of other characteristics, such as the color of the carapace and the scales that cover the head and limbs, carapace constriction, the size of the inguinal scute, the overlap of the gular scute, and the shape of frontal and pre-frontal scales prove to have an even more reliable classification, as suggested by several authors (Pritchard and Trebbau, 1984; Moskovits, 1988; Ernst and Barbour, 1989; Hagan, 1989; Jerozolimski, 2005; Vinke et al. 2008). The identification key for the species of Chelonoidis developed by Ernst and Barbour (1989) suggests the use of the gular scute as a differentiation criterion. However, the gular scute, which normally prolongs itself beyond the carapace in C. carbonaria may present the same characteristic in

Table 5. Analysis of sex dimorphism in Chelonoidis carbonaria and C. denticulate using carapace length (CL) as covariable (one-way Ancova).

\begin{tabular}{|c|c|c|c|c|c|c|c|c|c|c|}
\hline \multirow[b]{2}{*}{ Characteristic } & \multicolumn{5}{|c|}{ Chelonoidis denticulate } & \multicolumn{5}{|c|}{ Chelonoidis carbonaria } \\
\hline & $\begin{array}{c}\text { Male } \\
\text { (11) }\end{array}$ & $\begin{array}{c}\text { Female } \\
\text { (11) }\end{array}$ & $\mathbf{F}$ & p & $\begin{array}{l}\mathbf{M} / \mathbf{F} \\
(\%)\end{array}$ & $\begin{array}{c}\text { Male } \\
(80)\end{array}$ & $\begin{array}{c}\text { Female } \\
(53)\end{array}$ & $\mathbf{F}$ & $\mathbf{p}$ & $\begin{array}{l}\mathrm{M} / \mathrm{F} \\
(\%)\end{array}$ \\
\hline \multicolumn{11}{|l|}{$\overline{\text { Size }}$} \\
\hline $\mathrm{CL}$ & 328 & 342 & 0.32 & 0.5757 & -4.1 & 284 & 279 & 0.201 & 0.6546 & 1.8 \\
\hline Weight & 6316 & 5963 & 0.083 & 0.7756 & 5.9 & 4023 & 3899 & 0.019 & 0.8908 & 3.2 \\
\hline CCL & 428 & 419 & 7.656 & 0.0119 & 2.1 & 369 & 360 & 0.406 & 0.5253 & 2.5 \\
\hline CW5-6 (curved) & 355 & 386 & 3.062 & 0.0955 & -8.0 & 318 & 325 & 7.095 & 0.0087 & -2.2 \\
\hline SH2-3 & 131 & 137 & 0.331 & 0.5717 & -4.4 & 110 & 105 & 3.743 & 0.0552 & 4.8 \\
\hline SH3-4 & 142 & 147 & 0.177 & 0.6787 & -3.4 & 119 & 116 & 1.031 & 0.3118 & 2.6 \\
\hline SH6-7 & 146 & 153 & 0.838 & 0.371 & -4.6 & 122 & 127 & 15.297 & 0.0001 & -3.9 \\
\hline SH8-9 & 140 & 144 & 0.008 & 0.9305 & -2.8 & 120 & 121 & 4.266 & 0.0409 & -0.8 \\
\hline CW5-6 & 189 & 215 & 3.077 & 0.0947 & -12.1 & 169 & 176 & 22.328 & $<0.0001$ & -4.0 \\
\hline CW7-8 & 196 & 220 & 10.147 & 0.0046 & -10.9 & 178 & 175 & 0.069 & 0.7939 & 1.7 \\
\hline PL & 281 & 296 & 1.05 & 0.3178 & -5.1 & 227 & 225 & 0.067 & 0.7966 & 0.9 \\
\hline HSW & 138 & 143 & 0.159 & 0.6945 & -3.5 & 117 & 111 & 9.176 & 0.003 & 5.4 \\
\hline PS-AS & 177 & 196 & 9.204 & 0.0066 & -9.7 & 154 & 153 & 0.719 & 0.3981 & 0.7 \\
\hline EA-EF & 143 & 153 & 1.749 & 0.2009 & -6.5 & 117 & 109 & 11.402 & 0.0009 & 7.3 \\
\hline AS-FS & 98 & 92 & 7.03 & 0.0153 & 6.5 & 96 & 82 & 67.78 & $<0.0001$ & 17.1 \\
\hline ASL & 19 & 17 & 0.966 & 0.3375 & 11.8 & 14 & 9 & 52.128 & $<0.0001$ & 55.6 \\
\hline Bridge & 133 & 151 & 11.751 & 0.0027 & -11.9 & 108 & 119 & 94.619 & $<0.0001$ & -9.2 \\
\hline AX-IN & 106 & 123 & 11.299 & 0.0031 & -13.8 & 92 & 102 & 70.672 & $<0.0001$ & -9.8 \\
\hline HW & 42 & 45 & 2.751 & 0.1128 & -6.7 & 40 & 38 & 15.086 & 0.0001 & 5.3 \\
\hline HL & 64 & 66 & 0.107 & 0.7471 & -3.0 & 60 & 55 & 39.064 & $<0.0001$ & 9.1 \\
\hline
\end{tabular}


C. denticulata $(10.5 \%)$. We also recorded C. carbonaria individuals $(20 \%)$ whose gular scute did not overlap the carapace. Our data suggest that other measures of the plastron, when considered together, are more reliable in differentiating $C$. carbonaria from $C$. denticulata .

In spite of the typical constriction of $C$. carbonaria carapace, which nevertheless is not exclusive to the species (Pritchard and Trebbau, 1984; Ernst and Barbour, 1989), C. denticulata has been proved to have a more elongated shell (Moskovits, 1988; Jerozolimski, 2005). An elongated and angular front shell in $C$. denticulata facilitates moving around in a densely forested environment, where rounded shells such as those observed in $C$. carbonaria would hinder movements (Jerozolimski, 2005; Stevenson et al., 2007). Although the two species analyzed in the present study occur sympatrically in several regions, previous studies have shown that C. carbonaria prefers open areas, while $C$. denticulata chooses tropical, humid forests (Moskovits, 1988; Moreira, 1989; Farias et al., 2007). Chelonoidis carbonaria is more generalist and has been recorded in areas with highly contrasting temperature, humidity and vegetation cover variables (Jerozolimski, 2005). This distribution reveals the greater environmental plasticity of $C$. carbonaria, which also points to less intense selective environmental pressure on the shell shape. In Testudo marginata (Schoepff, 1793), a tortoise which inhabits areas with thick, well-packed vegetation, the shell is more elongated than in T. graeca (Linnaeus, 1758) and T. hermani (Gmelin, 1789), which inhabits typically more open areas in Greece. Larger and dome-shaped shells may render moving across vegetations difficult (Willemsen and Hailey, 2003). In a previous study with four species of the Testudo genus (Willemsen and Hailey, 2003), T. horsfieldii (Gray, 1844) was observed to dig long and deep burrows in sandy soil in deserts. It was also shown that the species exhibits less sexual dimorphism when compared to the other species of the genus inhabiting environments that do not impose locomotor restrictions and which promoted evolutionary traits which facilitate excavation (Willemsen and Hailey, 2003). The size and shape of four Gopherus species, a tortoise native to North America, have been proved to be unrelated to genetic differences and climate (Germano, 1993). Nevertheless, the distinctions in these species' skeletons and shapes of shells have been associated to different abilities to bury themselves in the ground (Morafka, 1982). Gopherus polyphemus (Daudin, 1802) and G. flaviomarginatus (Legler, 1959) present an appropriate osseous structure and shell shape that have undergone changes so as to facilitate digging longer tunnels in friable and sandy soils. In turn, G. agassizii (Cooper, 1863) and G. berlandieri (Agassiz, 1857) are better adapted to move around more quickly and to excavate harder soils, being structurally more primitive (Germano, 1993).

Selection processes play different roles in influencing the bodies of males and females (Lovich et al. 2010). In males, these processes increase the capacity to fight against other males and to mount on females (Berry and Shine, 1980). In females, these processes generate the accumulation of nutrients required in vitellogenesis and promote egg production (Bonnet et al., 2001; Lagarde et al., 2001, 2003; Stevenson et al., 2007). C. carbonaria presents a more significant sexual dimorphism than $C$. denticulata, which may be associated to different selective pressures acting in the evolution of shape (Pritchard and Trebbau, 1984; Moskovits, 1988; Ernst and Barbour, 1989; Jerozolimski, 2005). In C. denticulata, the more elongated shell, that favors motion across thick vegetation, may hamper the possibilities of variation in shape, similarly to what has been reported for Testudo (Willemsen and Hailey, 2003; Kaddour et al., 2008). In C. denticulata, the plastron is larger in comparison to $C$. carbonaria when CL is used as a covariable and the influence of size of individuals on the shape is excluded from the analysis. Larger plastrons afford greater protection to individuals, reducing exposure of limbs, though this trait also decreases mobility (Zuffi and Plaitano, 2007). In C. carbonaria, the shell and the opening for limbs and tail are wider. Further research on the way these species move may shed new light on whether these differences observed in shell openings are associated to the search for food resources and mating partners, or a response to different predators. Additionally, more information could be obtained about the possibility that this opening was shaped by sexual selection or that it is related to morphological differences (tail size, position of the cloaca; Jerozolimski, 2005) or to behavior during mating (Castaño-Mora and Lugo-Rugeles, 1981; Bonnet et al., 2001; Lagarde et al., 2003; Willemsen and Hailey, 2003; Kaddour et al., 2008). Nevertheless, the morphological data and motion rates of $C$. denticulata reported by Moskovits and Kiester (1987) and Jerozolimski et al. (2009) suggest that the differences in shell opening between males and females are more closely associated to reproductive behavior and protection against predators than to the motion of individuals. The rationale behind this hypothesis lies in the longer distances covered by females in the dry season, when these animals are apparently more exposed to predation, whereas males are more active and move across longer distances in the rainy season (Jerozolimski et al., 2009). In the Peruvian Amazon, C. denticulata males and females show the same distance ranges regardless of the season and age of individuals (Guzmán and Stevenson, 2008). Movement ranges (Guzmán and Stevenson, 2008) or sex-related differences in ranges (Moskovits and Kiester, 1987; Jerozolimski et al., 2009) are not enough to explain sexual dimorphism in the two species investigated.

Phenotypical variations and sexual dimorphism may be influenced by availability of food, while phenotypical plasticity determines the size of body and sexual dimorphism (Shine, 1989; Madsen and Shine, 1993; Pearson et al., 2002a,b). The difficulties in finding food or the differences in diets between males and females are not accountable for the variation in shell shape or the sexual dimorphism between species, since males have been demonstrated to have an identical diet (Moskovits and Bjordnal, 1990; Strong and Fragoso, 2006; Jerozolimski et al., 2009), in spite of the differences in distance ranges and areas they 
live in throughout the seasons (Moskovits and Kiester, 1987; Jerozolimski et al., 2009).

In comparison to males, abdomens of females of C. denticulata and C. carbonaria were larger, which can increase egg production. A similar pattern has been reported for Testudo horsfieldii, whose females are larger than males (Kaddour et al., 2008). Similarly, the females of both species were shown to have longer shells as compared to males, as observed in the measurements of AX-IN, CW5-6, PL, and CCL. Longer AX-IN and CW5-6 reflect larger abdomens. Larger plastrons and inguinal scutes lend more protection to females against predators.

The morphometric descriptors ASL, FMSL, and HSW were larger in females, while AX-IN and the inguinal scute were greater in males. This proves to have wider openings for limbs, conferring more mobility to males and greater protection to females. AX-IN is inversely correlated with a mobility degree. Species with greater mobility, such as the genera Emys, Trachemys, Lysemys and Pelomedusa, have shorter AX-IN in comparison to tortoises (Zuffi and Plaitano, 2007). When the same taxon is considered, larger AX-IN is observed in females, which decreases female mobility, as compared to males (Lebboroni and Chelazzi, 1991; Corti and Zuffi, 2003; Zuffi and Plaitano, 2007). Middle scutes in the plastron are laterally connected to the carapace and influence shell opening less directly, although the changes they present play a role in the definition of plastron concavity (Kaddour et al., 2008). The males present larger abdominal scutes (PS-AS), and the differences are associated mainly to plastron concavity. Longer PS-AS values are associated to the development of the concavity that presses the suture towards the outer plastron. This larger concavity can give more stability to males during copulation (Castaño-Mora and Lugo-Rugeles, 1981; Moskovits 1988; Willemsen and Hailey, 2003).

A wide array of signals is observed in the interaction between adult males and in courtship combats (demonstration of colored dermal plates), body language (as in head movements), and fight strategies (Auffenberg, 1965; Davis, 1979; Castaño-Mora and Lugo-Rugeles, 1981; Pritchard and Trebbau, 1984). Males have larger and longer heads as compared to females, a common characteristic in male tortoises, for which courtship combats are frequent. Concerning combats, a more robust head has advantages, mainly in species that habitually bite the limbs of contenders during these fights or that even impose themselves upon females (Castaño-Mora and Lugo-Rugeles, 1981; Davis, 1979). Longer heads are useful also in the maneuvers adopted in order to roll back to the normal position on the ground, during combats (Auffenberg, 1969; Bonnet et al., 2001). As regards head size, evolution led to opposing sexual dimorphisms in $C$. denticulata and $C$. carbonaria. In the former, males have larger heads than females, while in $C$. denticulata the opposite is observed. These differences may be related to more complex courtship or combat rituals in C. carbonaria. Studies addressing the influence of shape in reproductive success may shed new light on this subject.
The differences in carapace shape show the effects of sexual selection and selection for fecundity with larger and better protected females, which is an advantage against predators. Apart from this, these differences show that females have higher numbers of hatchlings and lay larger eggs (Wilbur and Morin, 1988; Gibbons and Greene, 1990; Iverson, 1992; Batistella and Vogt, 2008). Chelonoidis carbonaria is the species with the least restrictions to shape, showing a higher sexual dimorphism as compared to $C$. denticulata. Our data do not indicate sexual dimorphism associated to size and weight in the two species, also commonly observed in other species such as Geochelone pardalis (Bell, 1828) (Lambert et al., 1998) and in the tortoises of the genera Testudo (Lagarde et al., 2001, 2003; Kaddour et al., 2008) and Gopherus (Germano, 1993). However, our data may have been subject to some bias due to the fact that our sample was formed by captive animals. Based on the data from several sources of Colombian, Venezuelan, Guyanese, French Guyanese, Surinamese, Peruvian, and Brazilian populations, Pritchard and Trebbau (1984) stated that, on average, males are larger than females, although as far as exceptionally larger specimens are concerned, females are larger than males.

In a study on populations native to southern Pará, a Brazilian state in the Amazon region, Jerozolimski (2005) reported that some individuals of $C$. carbonaria are larger and heavier than $C$. denticulata, a pattern that is different from that observed in other areas (Pritchard and Trebbau, 1984; Ernst and Barbour, 1989). These differences may be due to numerous factors related to sampling (seasonality, collection strategy, sampling effort), environment conservation status and anthropic activities in the area (pressure caused by hunting and deforestation), and evolutive history (predatory, availability of food resources). The authors also draw attention to the difficulties inherent to working with species that may present low population density and that take cryptic habits.

Morphometry was proved useful to discriminate the two species, considering the individuals evaluated in the present study. A more evident sexual dimorphism was observed in C. carbonaria as compared to C. denticulata. The most important variables in the differentiation between species are associated to the dimension of plastron scutes and to carapace curvature and constriction. In sex identification, the most important variables are associated to the plastron, carapace width and head length.

Acknowledgements - We would like to thank the Zoológico do Centro de Biodiversidade da USIPA/CEBUS, especially LC. Silva and CDP. Coelho for the support in data collection and MM. Espírito-Santo for helping with statistics analyses. We would also like to thank the Centro Universitário do Leste de Minas Gerais (UnilesteMG) for the scholarship awarded to MS. Barros and LC. Resende.

\section{References}

AUFFENBERG, W., 1965. Sex and species discrimination in two sympatric South American tortoises. Copeia, vol. 1965, no.3, p. 335-342. 
-, 1969. Social behavior of Geochelone denticulata. Quarterly Journal of the Florida Academy of Sciences, vol. 32, no. 1, p. 50-58.

BATISTELLA, AM. and VOGT, RC., 2008. Nesting ecology of Podocnemis erythrocephala (Testudines, Podocnemididae) of the Rio Negro, Amazonas, Brazil. Chelonian Conservation and Biology, vol. 7, no. 1, p. 12-20. http://dx.doi.org/10.2744/ CCB-0611.1

BERRY, JF. and SHINE, R., 1980. Sexual size dimorphism and sexual selection in turtles (order Testudines). Oecologia, vol. 44, no. 2, p. 185-191. http://dx.doi.org/10.1007/BF00572678

BONNET, X., LAGARDE, F., HENEN, BT., CORBIN, J., NAGY, KA., NAULLEAU, G., BALHOUL, K., CHASTEL, O., LEGRAND, A. and CAMBAG, R., 2001. Sexual dimorphism in steppe tortoises: influence of the environment and sexual selection on body shape and mobility. Biological Journal of the Linnean Society, vol. 72, no. 3, p. 357-372. http://dx.doi. org/10.1111/j.1095-8312.2001.tb01323.x

BOONE, JL. and HOLT, EA., 2001. Sexing young free-ranging desert tortoises (Gopherus agassizii) using external morphology. Chelonian Conservation and Biology, vol. 4, no. 1, p. 28-33.

CASTAÑO-MORA, OV. and LUGO-RUGELES, M., 1981. Estudio comparativo del comportamiento de los especies de morrocoy: Geochelone carbonaria y Geochelone denticulata y aspectos comparables de su morfología externa. Cespedesia, vol. 10 , no. 1 , p. 55-122.

CORTI, C. and ZUFFI, MAL., 2003. Aspects of population ecology of Testudo hermanni hermanni from Asinara Island, NW Sardinia (Italy, Western Mediterranean Sea): preliminary data. Amphibia-Reptilia, vol. 24, no. 4, p. 441-447. http://dx.doi. org/10.1163/156853803322763909

DAVIS, S., 1979, Husbandry and breeding of the Red-footed tortoise, Geochelone carbonaria, at the National Zoological Park, Washington. International Zoo Yearbook, vol. 19, no. 1, p. 50-53. http://dx.doi.org/10.1111/j.1748-1090.1979.tb00524.x

DELMAS, V., BAUDRY, E., GIRONDOT, M. and PRÉVOTJULLIARD, AC., 2007. The righting response as a fitness index in freshwater turtles. Biological Journal of the Linnean Society, vol. 91, no. 1, p. 99-109. http://dx.doi.org/10.1111/j.10958312.2007.00780.x

ERNST, CH. and BARBOUR, RW., 1989. Turtles of the World. Washington: Smithsonian Institution Press. 313 p.

FARIAS, IP., JEROZOLIMSKI, A., MELO, A., VIANA, MN., MARTINS, M. and MONJELÓ, LAS., 2007. Population genetics of the Amazonian tortoises, Chelonoidis denticulata and $C$. carbonaria (Cryptodira: Testudinidae) in an area of sympatry. Amphibia-Reptilia, vol. 28, no. 3, p. 357-365. http://dx.doi. org/10.1163/156853807781374836

FERNÁNDEZ, CA. and RIVERA, AC., 2003. Sexual dimorphism and morphological differentiation in European pond turtle (Emys orbicularis) populations from Northwesrn Spain. Chelonian Conservation and Biology, vol. 4, no. 1, p. 100-106.

GERMANO, DJ., 1993. Shell morphology of North American tortoises. The American Midland Naturalist, vol. 129, no. 2, p. 319-335. http://dx.doi.org/10.2307/2426513

GIBBONS, JW. and GREENE, JL., 1990. Reproduction in the slider and other species of turtles. In GIBBONS, JW. Life history and ecology of the Slider Turtle. Washington: Smithsonian Institution Press. p. 124-134.
GUIX, JC., FEDULLO, DL. and MOLINA, FB., 2001. Masculinization of captive females of Chelonoidis carbonaria (Testudinidae). Revista Española de Herpetología, vol. 15, no. 1., p. 67-75.

GUZMÁN, A. and STEVENSON, PR., 2008. Seed dispersal, habitat selection and movement patterns in the Amazonian tortoise, Geochelone denticulata. Amphibia-Reptilia, vol. 29, no. 4 , p. $463-472$.

HAGAN, JW., 1989. Differentiating Geochelone denticulata and Geochelone carbonaria. Tortuga Gazette, vol. 25, no. 4, p. 3-4.

IVERSON, JB., 1992. Correlates of reproductive output in turtles (order Testudines). Herpetological Monographs, vol. 6, no. 1 , p. 25-42.

JEROZOLIMSKI, A., 2005. Ecologia de populações silvestres dos jabutis Geochelone denticulata e G. carbonaria (Cryptodira: Testudinidae) no território da aldeia A'Ukre, TI Kayapó, sul do Pará. São Paulo: Instituto de Biociências, Universidade de São Paulo. 242 p. Tese de Doutorado em Ecologia.

JEROZOLIMSKI, A., RIBEIRO, MBN. and MARTINS, M., 2009. Are tortoises important seed dispersers in Amazonian forests? Oecologia, vol. 161, no. 3, p. 517-528. PMid:19575239. http://dx.doi.org/10.1007/s00442-009-1396-8

KADDOUR, K.B., El MOUDEN, H., SLIMANI, T., BONNET, X. and LAGARDE, F., 2008. Sexual dimorphism in the Greek tortoise: a test of the body shape hypothesis. Chelonian Conservation and Biology, vol. 7, no. 1, p. 21-27. http://dx.doi.org/10.2744/ CCB-0649.1

LAGARDE, F., BONNET, X., HENEN, B., LEGRAND, A., CORBIN, J., NAGY, K. and NAULLEAU, G., 2001. Sexual dimorphism in steppe tortoise (Testudo horsfieldi): growth, maturity, and individual variation. Canadian Journal of Zoology, vol. 79 , no. 8 , p. 1433-1441.

LAGARDE, F., BONNET, X., HENEN, B., LEGRAND, A., CORBIN, J., NAGY, K. and NAULLEAU, G., 2003. Sex divergence in space utilisation in the steppe tortoise (Testudo horsfieldi). Canadian Journal of Zoology, vol. 81, no. 3, p. 380-387. http://dx.doi.org/10.1139/z03-023

LAMBERT, MRK., CAMPBELL, KLI. and KABIGUMILA, JD., 1998. On growth and morphometrics of leopard tortoises, Geochelone pardalis, in Serengeti National Park, Tanzania, with observations on effects of bushfires and latitudinal variation in populations of eastern Africa. Chelonian Conservation and Biology, vol. 3, no, 1, p. 46-57.

LEARY, CJ., DOBIE, JL., MANN, TM. and FLOYD, PS., 2003. Morphological variation in the endangered Alabama red- bellied cooter (Pseudemys alabamensis) and taxonomic status of a population in Mississipi. Chelonian Conservation and Biology, vol. 4 , no. 3, p. 635-641.

LEBBORONI, M. and CHELAZZI, G., 1991. Activity patterns of Emys orbicularis L. (Chelonia Emydidae) in Central Italy. Ethology, Ecology \& Evolution, vol. 3, no. 3, p. 257-268. http://dx.doi.org/10.1080/08927014.1991.9525373

LINDEMAN, PV., 2003. Diagnostic characteristics in lower Tennessee river populations of the map turtles Graptemys pseudogeographica and Graptemys ouachitensis. Chelonian Conservation and Biology, vol. 4, no. 3, p. 564-568.

LOVICH, JE., ZNARI, M., BAAMRANE, MA., NAIMI, M. and MOSTALIH, A., 2010. Biphasic geographic variation in sexual size dimorphism of turtle (Mauremys leprosa) populations along 
an environmental gradient in Morocco. Chelonian Conservation and Biology, vol. 9, no. 1, p. 45-53. http://dx.doi.org/10.2744/ CCB-0788.1

MADSEN, T. and SHINE., R., 1993. Phenotypic plasticity in body sizes and sexual dimorphism in European grass snakes. Evolution, vol. 47, no. 1, p. 321-325. http://dx.doi.org/10.2307/2410141

MOREIRA, G., 1989. Sympatry of turtles Geochelone carbonaria and Geochelone denticulata in the Rio Uatumã basin, Central Amazonia. Journal of Herpetology, vol. 23, no. 2, p. 183-185. http://dx.doi.org/10.2307/1564029

MORAFKA, DJ., 1982. The status and distribution of the Bolson tortoise (Gopherus flavomarginatus). In BURY, RB. North American tortoises: conservation and ecology. Washington: US Department of the Interior, Fish, Wildlife Service. p. 71-94. Wildlife Research Report, no. 12.

MOSKOVITS, D., 1988. Sexual dimorphism and population estimates of the two Amazonian tortoises (Geochelone carbonaria and G. denticulata) in Northwestern Brazil. Herpetologica, vol. 44, no. 2, p. 209-217.

MOSKOVITS, DK. and KIESTER, AR., 1987. Activity levels and ranging behaviour of the two amazonian tortoises, Geochelone carbonaria and Geochelone denticulata, in North-Western Brazil. Functional Ecology, vol. 1, no. 3, p. 203-214. http://dx.doi. org/10.2307/2389422

MOSKOVITS, D. and BJORNDAL, KA., 1990. Diet and food preferences of the tortoises Geochelone carbonaria and $G$. denticulata in Northwestern Brazil. Herpetologica, vol. 42, no. 2, p. 207-218.

PEARSON, D., SHINE, R. and HOW, R., 2002a. Sex-specific niche partitioning and sexual size dimorphism in Australian pythons (Morelia spilota imbricata). Biological Journal of the Linnean Society, vol. 77, no. 1, p. 113-125. http://dx.doi. org/10.1046/j.1095-8312.1999.00075.x

PEARSON, D., SHINE, R. and WILLIAMS, A., 2002b. Geographic variation in sexual size dimorphism within a single snake species (Morelia spilota, Pythonidae). Oecologia, vol. 131, no. 4, p. 418-426. http://dx.doi.org/10.1007/s00442-002-0917-5

PRITCHARD, PCH. and TREBBAU, P., 1984. Geochelone (Chelonoidis) carbonaria (Spix, 1824) and Geochelone (Chelonoidis) denticulata (Linnaeus, 1766). In PRITCHARD, PCH. and
TREBBAU, P. (Eds.). The Turtles of Venezuela. Caracas: Society of Study of Amphibians and Reptiles. p. 207-231.

SHINE, R., 1989. Ecological causes for the evolution of sexual dimorphism: a review of the evidence. The Quarterly Review of Biology, vol. 64, no. 4, p. 419-431. PMid:2697022. http://dx.doi. org/10.1086/416458

SOUZA, VL., SANTOS, TM., PEÑA, AP., LUZ, VLF. and REIS, IJ., 2007. Caracterização dos répteis descartados por mantenedores particulares e entregues ao Centro de Conservação e Manejo de Répteis e Anfíbios - RAN. Revista de Biologia Neotropical, vol. 4 , no. 2, p. 149-160.

STEVENSON, PR., BORDA, CA., ROJAS, AM. and ALVAREZ, M., 2007. Population size, habitat choice, and sexual dimorphism of the Amazonian tortoise (Geochelone denticulata) in Tinigua Park, Colombia. Amphibia-Reptilia, vol. 28, no. 2, p. 217-226. http://dx.doi.org/10.1163/156853807780202459

STRONG, JN. and FRAGOSO, JMV., 2006. Seed dispersal by Geochelone carbonaria and Geochelone denticulata in Northwestern Brazil. Biotropica, vol. 38, no. 5, p. 683-686. http://dx.doi.org/10.1111/j.1744-7429.2006.00185.x

VANZOLINI, PE., 1999. A note on the reproduction of Geochelone carbonaria and G. denticulata (Testudines, Testudinidae). Brazilian Journal of Biology, vol. 59, no. 4, p. 593-608.

VINKE, S., VETTER, H., VINKE, T. and VETTER, S., 2008. South American tortoises: Chelonoidis carbonaria, C. denticulate, and C. chilensis. Philadelphia: Edition Chimaira, v. 3, p. 355.

WILBUR, HM. and MORIN, PJ., 1988. Life history evolution in turtles. In GANS, DC. and HUEY, B. Biology of the Reptilia. New York: Alan R. Liss. vol. 16, p. 387-437.

WILLEMSEN, RE. and HAILEY, A., 2003. Sexual dimorphism of body size and shell shape in European tortoises. Journal of Zoology, vol. 260, no. 4, p. 353-365. http://dx.doi.org/10.1017/ S0952836903003820

ZAR, JH., 2009. Biostatistical Analysis. 5nd ed. Englewood Cliffs: Prentice Hall. 960 p.

ZUFFI, MA. and PLAITANO, A., 2007. Similarities and differences in adult tortoises: a morphological approach and its implication for reproduction and mobility between species. Acta Herpetologica, vol. 2, no. 2, p. 79-86. 
